\title{
Clofibrate and Fat Embolism: A Double-Blind Trial of the Effects of Clofibrate on Sequelae to Injury
}

\author{
W. G. COLE
}

British Medical fournal, 1971, 4, 148-149

\section{Summary}

In a double-blind prospective trial clofibrate was found not to influence significantly the clinical and laboratory indices thought to reflect the state of fat embolism in patients with fractures.

\section{Introduction}

In 1967 O'Driscoll and Powell reported that clofibrate reduced the incidence and severity of fat embolism after fractures. Their study was open to several criticisms-the methods used to select patients were not given, it was not apparent whether a method of randomization was used to allocate patients to the treated and control group, there were differences in the numbers of patients included in the two groups, and though the proportions of patients having fractures and elective orthopaedic procedures in the two groups differed the results in these groups were combined.

Because a clear demonstration that the risks of fat embolism could be reduced would be an important therapeutic advance, it was decided to re-examine the effect of clofibrate in a double-blind prospective trial. This paper reports such a trial in which the effects of clofibrate and a placebo were compared on changes in respiratory function, cerebral function, the retina, and the skin in patients admitted with fractures. The study was formulated in these terms because of the difficulties encountered when an attempt is made to define fat embolism as a clinical entity.

\section{Patients and Methods}

All patients with fractures of the shafts of the long bones and/or pelvis who were admitted to the Royal Melbourne Hospital during 1969 and 1970 were considered for enrolment in the trial. According to the protocol those enrolled had to be free from associated chest, head, or abdominal injuries and of known pre-existing disease of the lungs or brain. Of the 273 patients considered for the trial 119 fulfilled the necessary criteria for enrolment.

On entering the trial the patients were randomly allocated to receive either capsules containing $250 \mathrm{mg}$ of clofibrate or capsules containing olive oil which were identical in appearance. The trial was conducted on a double-blind basis, the code being broken only at the conclusion. Four capsules were given twice a day for six days, starting as soon as possible after admission. This dose was selected as it had been shown to be effective in reducing raised serum triglyceride levels in other types of patients (Berkowitz, 1965).

The patients were studied for six days after injury. Daily clinical examinations were made to seek physical signs in the chest, central nervous system, and skin. On the first and sixth days the retinae were examined with a Keeler indirect ophthalmoscope after dilating the pupil with $10 \%$ neostigmine drops. The method of Carlson (1959) was used to determine

\footnotetext{
University of Melbourne Department of Medicine, the Royal Melbourne Hospital, Victoria 3050

W. G. COLE, M.B., B.S., Research Fellow
}

the serum triglyceride levels in blood collected in the fasting state from arm veins on the first, second, third, and sixth days. Urine was also collected on these days, stained with Sudan III, and examined with a microscope to detect fat globules. On the first, second, and sixth days the partial pressure of oxygen $\left(\mathrm{PaO}^{2}\right)$ was measured on brachial artery blood with a Beckman modular curvette containing a macro-oxygen electrode connected to a physiological gas amplifier model 160 . The $\mathrm{PaO}_{2}$ meter readings were corrected by the method of Rogers et al. (1968). In eight randomly selected patients serial clofibrate levels in fasting serum samples were determined by I.C.I. Ltd., Great Britain.

\section{Results}

The type of fractures in the two treatment groups are listed in Table I. Randomization of the patients to the clofibrate and placebo groups was found to have been satisfactory in terms of the distribution of the types of fracture, age, and sex (Table II).

There were no deaths in either group. No differences were detected between the treatment groups in the clinical indices except for the skin petechiae, which were found more often in the clofibrate group. Four of the eight patients with tachypnoea had bilateral widespread rales and crepitations. All but one of the patients with rhonchi smoked more than 20 cigarettes each day. The cerebral abnormalities consisted of dis-

TABLE I-Types of Fractures

\begin{tabular}{|c|c|c|c|c|}
\hline \multirow{2}{*}{\multicolumn{2}{|c|}{ Fractures }} & \multicolumn{2}{|c|}{ No. of Patients } & \multirow{2}{*}{ Total } \\
\hline & & Clofibrate & Placebo & \\
\hline $\begin{array}{l}\text { Pelvis } \ldots \\
\text { Femur .. } \\
\text { Tibia and fibula } \\
\text { Upper limb } \\
\text { Multiple }\end{array}$ & $\begin{array}{l}\ldots \\
\cdots \\
\cdots \\
\cdots\end{array}$ & $\begin{array}{r}10 \\
16 \\
18 \\
7 \\
10\end{array}$ & $\begin{array}{r}9 \\
19 \\
17 \\
3 \\
10\end{array}$ & $\begin{array}{l}19 \\
35 \\
35 \\
10 \\
20\end{array}$ \\
\hline
\end{tabular}

Excluding those with upper limb fractures $\gamma^{2}=0.3284$ for 3 D.F. P $>0.9$

\begin{tabular}{|c|c|c|c|c|}
\hline Indices & Clofibrate & Placebo & Test & $\mathbf{P}$ \\
\hline No. of Patients & 61 (42M., 19F.) & 58 (46M., 12F.) & $\chi^{2}=1.886$ d.f. & $>0 \cdot 1$ \\
\hline$\underset{\text { Fale }}{\text { Male }} \cdots$ & $\begin{array}{c}35 \cdot 7 \pm 14 \cdot 7 \\
44 \cdot 1 \pm 23 \cdot 4\end{array}$ & $\begin{array}{c}35.2 \pm 18.4 \\
42.7 \pm 21.9\end{array}$ & $\begin{array}{l}t=0.1404 \text { 86d.f. } \\
t=0.165 \text { 19d.f. }\end{array}$ & $\begin{array}{l}>0.4 \\
>0.4\end{array}$ \\
\hline $\begin{array}{l}\text { Clinical indices: } \\
\text { Deaths }\end{array}$ & $----e^{-}$ & 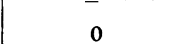 & & \\
\hline $\begin{array}{l}\text { Skin petechiae } \\
\text { Tachypnoea } \\
\text { (Resp. } \geqslant 25 / \mathrm{min} \text { ) }\end{array}$ & $\begin{array}{r}14 \\
4\end{array}$ & $\begin{array}{l}6 \\
4\end{array}$ & $x^{2}=2.5381$ d.f. & $>0 \cdot 1$ \\
\hline $\begin{array}{l}\text { Rhonchi } \\
\text { Cerebral }\end{array}$ & 13 & 18 & $\varkappa^{2}=0.998$ 1.d.f. & $>0.3$ \\
\hline $\begin{array}{l}\text { abnormalities } \\
\text { Retinal }\end{array}$ & 3 & 2 & & \\
\hline $\begin{array}{c}\text { abnormalities } \\
\text { Laboratory indices: }\end{array}$ & 0 & 0 & & \\
\hline $\begin{array}{l}\text { Urinary fat } \\
\mathrm{PaO}_{2}(\mathrm{~mm} \mathrm{Hg}):\end{array}$ & 20 & 22 & $\varkappa^{2}=0.156$ 1d.f. & $>0.7$ \\
\hline $\begin{array}{ll}\text { Day } 1 & \ldots \\
\text { Day } 2 & \ldots \\
\text { Day } 6 & \ldots\end{array}$ & $\begin{array}{l}85.1 \pm 16.8 \\
89.1 \pm 17.5 \\
93.6 \pm 14.7\end{array}$ & $\begin{array}{l}85.3 \pm 18.2 \\
87.1 \pm \pm 20.2 \\
93.5\end{array}$ & $\begin{array}{l}t=0.0312 \text { 117d.f. } \\
t=0.5793 \text { 117d.f. } \\
t=0.0354 \text { 117d.f. }\end{array}$ & $\begin{array}{l}>0.9 \\
>0.6 \\
>0.9\end{array}$ \\
\hline $\begin{array}{l}\text { Serum triglycerides } \\
(\mathrm{mg} / 100 \mathrm{ml}):\end{array}$ & -12 & (1001 & $t=0.030411 /$ a.r. & \\
\hline $\begin{array}{cc}\text { Day } 1 & \ldots \\
\text { Day } 2 & \ldots\end{array}$ & $\begin{array}{l}112.6 \pm 44 \cdot 4 \\
114.2 \div 37\end{array}$ & $94.4 \pm 37.1$ & $t=1.9102$ 72d.f. & $\begin{array}{l}<0.05 \\
>0.2\end{array}$ \\
\hline Day 3 & $112.9 \pm 36.3$ & $121.4 \pm 38.3$ & $t=0.959472$ d.f. & $>0.3$ \\
\hline Day 6 & $120 \mp 36$ & $127 \pm 45.9$ & $t=0.668572$ d.f. & $>0.5$ \\
\hline
\end{tabular}


orientation and drowsiness and in one patient a hemiparesis with aphasia. Retinal abnormalities attributable to the injury were not detected in either treatment groups.

Significant differences between the treatment groups were not found in the incidence of urinary fat droplets or in the level of $\mathrm{PaO}_{2}$. No reason was found for the difference in the serum triglyceride levels on the first day before treatment was started. Such differences were not found on the other days. The levels of serum clofibrate in $\mu \mathrm{g} / \mathrm{ml}$ were: Day 2, $127 \pm$ 88; Day 3, 149 \pm 56 ; Day 6, $110 \pm 68$. There were no significant differences between the treatment groups in any of several detailed tests of respiratory or liver function which were performed and which will be reported elsewhere.

\section{Discussion}

Measurement of blood levels shows that the clofibrate administered was absorbed, and the lesser rise in serum triglycerides in the treated group indicated that it exerted one of its wellknown effects. The indices commonly used to characterize fat embolism did not differ between the groups. Indeed one of the most commonly mentioned indices-skin petechiae-occurred more often in the colifibrate group. Significant differences were not found when the clinical and laboratory indices were grouped according to O'Driscoll and Powell's (1967) major and minor criteria of fat embolism. The possibility remains that fat embolism might have occurred before adequate blood levels of clofibrate were achieved by the oral preparation. Further studies with an intravenous preparation of clofibrate would be necessary to exclude this possibility. At present an intravenous preparation is not available.

A striking finding in this study was the frequency with which low levels of $\mathrm{PaO}_{2}$ were found in patients in whom no clinical respiratory abnormality was detected despite careful and repeated examinations.

I wish to thank Professor R. R. H. Lovell and Dr. M. A. Denborough for their advice and criticism; Dr. C. Proctor, medical director of I.C.I.A.N.Z. Ltd., for his financial assistance; Mr. W. E. Swaney and Mr. K. Mills for their advice and permission to study patients under their care; Dr. M. Pain and staff for the respiratory analyses; Dr. P. Cowling for the urinary fat analyses; Mr. N. Naismith for randomizing the drug administration; and Dr. R. Prineas for his statistical advice.

\section{References}

Berkowitz, D. (1965). Metabolism, 14, 966.

Carlson, L. A. (1959). Acta Societatis Medicorum Upsaliensis, 64, 208.

O'Driscoll, M., and Powell, F. J. (1967). British Medical fournal, 4, 149.

Rogers, N., Laver M., and Pain, M. C. F. (1968). Medical fournal of Austialia, 2, 585 .

\title{
Skin Collagen and Thickness in Simple Obesity
}

\author{
MARTIN M. BLACK， EVA BOTTOMS， SAM SHUSTER
}

British Medical fournal, 1971, 4, 149-150

\section{Summary}

The effects of stretching of the skin on its collagen content and thickness have been studied in a group of subjects with chronic obesity. Despite the increase in skin surface a normal skin thickness, collagen content, and density were maintained. It is concluded that the skin stretching induced by prolonged obesity led to hypertrophy of collagen and that this had maintained both skin thickness and collagen content. It is not known whether this is due to enhanced synthesis or decreased degradation.

\section{Introduction}

Skin collagen content is best expressed as a function of the surface area of the biopsy, and using this expression we have demonstrated changes in the normal with age, sex, site of biopsy, and in diseases of the endocrines, bones, and connective tissues (Shuster and Bottoms, 1963; Shuster et al., 1967a, 1967b; Black et al., 1970a, 1970b, 1970c; Stevenson et al., 1970). The question which now arises is whether the idea of relating skin collagen to surface area remains valid when skin is abnormally stretched. We therefore measured forearm skin collagen in patients with obesity of

\footnotetext{
University Department of Dermatology, Royal Victoria Infirmary, Newcastle upon Tyne NE1 4IP

MARTIN M. BLACK, M.D., M.R.C.P., Registrar (Present Address: St. Ichn's Hospital for Discases of the Skin, Leicester Square, London W.C.2)

EVA BOTTOMS, B.SC., Senior Research Associate

SAM SHUSTER, PH.D., F.R.C.P., Professor of Dermatology
}

long duration. We measured skin thickness at the same time, since we have also shown that skin thickness, as measured histologically or radiologically, and skin collagen are directly related (unpublished observations).

\section{Patients and Methods}

Sixteen patients with "simple" obesity were studied. Six were males aged 19-36 years and 10 were females aged 15 to 57 years. None had diabetes mellitus, myxoedema, hypogonadism or Cushing's syndrome. All were considerably overweight; and none was less than $30 \%$ above the average weight predicted from the age and height (Metropolitan Life Insurance Company, 1959). The body surface area for each subject was estimated, height and weight nomogram (Dubois and Dubois, 1915) being used. The "ideal" surface area was then obtained for each subject, using their "ideal" body weight as obtained from their age, height and sex. Forearm circumference was measured at the mid-point of the arm both in the obese patients and in a group of normal subjects (13 male and 13 female) of the same age range as the obese patients.

Skin thickness was measured by the radiographic method of Meema et al. (1964) as modified by Black (1969). The results were age matched and compared with our data for 90 normal adult males and 107 females (unpublished observation)

Total skin collagen was measured by the method of Shuster and Bottoms (1963) as follows: skin biopsy specimens were taken from the mid-point of the extensor aspect of the forearm with a high speed rotary punch of $5 \mathrm{~mm}$ diameter. The specimens were defatted in acetone and then dried to constant weight. After hydrolysis the hydroxyproline content was measured by the method of Woessner (1961) and 